\title{
Massive Open Online Courses as an Augmentation of E-Learning: A Review
}

\author{
Mohamed Ali Mahmod, Asma Binti Md. Ali and Asadullah Shah \\ Dept. of Information Systems, International Islamic University Malaysia, Kuala Lumpur, Malaysia \\ mmashadani@gmail.com \\ Sis_asma@iium.edu.my \\ asadullah@iium.edu.my
}

Abstract- Massive Open Online Courses (MOOCs) are considered as important trends in electronic learning (e-learning) in higher education. Many universities offered MOOCs to any learners who prefer learning via the internet and benefiting from the offered courses online. Massive Open Online Courses are open learning to anyone to enrol and study and many offered courses are free which do not require paying fees. MOOCs are delivered as video-based content via the internet offered by educational institutions and universities to many international learners. There is a lack of previous studies and scientific papers that investigates the global role of MOOCs in e-learning. MOOCs has emerged due to learning theories related to learners whether individuals or networks of learners. Therefore, this paper reviews Massive Open Online Courses characteristics, it spread around the world, its practical implementation in e-learning Learning Management Systems (LMS) and its theoretical contributing roles to enhance e-learning through its roles in promoting e-learning theories.

Keywords - Massive Open Online Courses, Electronic learning, distance learning

\section{INTRODUCTION}

Massive Open Online Courses (MOOCs) have emerged as important means of learning via the internet due to the rapid adoption by universities and educational institutions worldwide. Over the years, the creative learning model of MOOCs have played a crucial role in promoting e-learning in prestigious international universities. Numerous universities have collaborated and partnered with the pioneer institutions in offering open online courses to learners. Millions of participants in these courses including learners and teachers have benefited from the collaboration among universities with MOOCs' institutions. In the initial distance learning model, a student received texts and curriculum via digital postal service. In return, a student submitted assignment and projects to the learning providers [1].

Researchers and open universities have continued to address learner skills and teaching practices by developing new learning processes. The recent trend of promoting MOOC by researchers and universities is also a result of researchers and universities adapting with recent technologies and innovation. The increase of interests in learning and teaching processes among Universities and companies has resulted in the New York Times announcing that the year of 2012 was the year of MOOC [2].

\section{MOOCS AROUND THE WORLD}

There are numerous educational institutions that offer MOOCs around the world. In 2012, Coursera appeared as an independent institution in offering online courses followed by other institutions such as Udacity and Udemy. Many international MOOCs institutions appeared in all different continents. In North and Latin America, there seems to be three dominant MOOCs providers: Coursera, Udacity and edX [3]. Dozens of universities in Mexico and Canada have partnered with the famous American MOOCs providers [4]. In Europe, twelve British universities have launched "FutureLearn" MOOC [5]. Other European MOOCs appeared such as "Iversity" MOOC in Germany [6,7], "FairstartGlobal" in Denmark and others [8]. In Asia, five Taiwan universities and mainland China have launched "ewant" MOOCs [9], while in Japan "JMOOC" was established in November 2013 [10]. In Malaysia, "OpenLearning" platform was chosen for the implementation to launch "MalaysiaMOOC" by twenty public universities [11]. In the Arab region, some MOOCs appeared such as "Edraak" in Jordan [12], "Rwaq" in Saudi Arabia [13], "MenaVersity" in Lebanon [14] and "SkillAcademy" in Egypt [15]. In Africa, "RESCIF" MOOCs was established in 2013 as a result of the collaboration among 15 universities [16].

\section{MOOCS IMPLEMENTATIONS IN E-LEARNING}

The practical implementation of MOOC can play a crucial role in promoting e-learning through its contributing to enhance Learning Management System (LMS). LMS is defined as an online portal that connects lecturers and students through providing classroom materials or shared activities. In addition, LMS also enables lecturers and students to interact out of the classroom and having discussions through forums [17]. Ramirez [18] described 
research based on the first $M O O C$ in Latin America which was offered by a network of academics from ten Mexican universities and using Blackboard as its LMS. Moodle is a free LMS which is considered as one of the most used LMS in universities. Moodle LMS can be enhanced by MOOC by promoting collaborative modules through providing a possibility of organizing collaborative activities through workshops, wikis and virtual labs [19]. The evolution in using MOOC in e-learning with LMS can be enhanced through Service Oriented Software (SOA) by making it available for mobile devices and native applications for iOS, Android, Linux and Windows operating systems. These services could be integrated with LMS portal in order to promote the collaborative work with electronic lectures such as live scripting $[20,21]$. Moreover, e-learning can be enhanced by MOOC through depending on cloud-based tools such as offering videos and documents stored on clouds such as Google Drive, Microsoft One Drive, and others for learners. Hence, e-learning can be enhanced by $M O O C$ through making it embedded in LMS and using it as cloud-based tools by offering videos and documents stored on clouds and developing it as SOA.

\section{TYPES OF MOOCS AND LEARNING THEORIES}

CMOOC and $x M O O C$ are the most common types of MOOCs. CMOOC is derived from the 'connectivism learning' theory which concentrates on creating and relating divided nets of learners and lecturers, information, and resources that relate knowledge to each other [22]. Sharing knowledge among others across the nets is considered the most crucial role of $\mathrm{CMOOC}$ [23].
On the other hand, $x M O O C$ focuses on contents and defined as content-based MOOC. XMOOCs are derived from 'cognitive-behaviorist learning' theory 'cognitive-behaviorist learning' theory which its learning process is described as 'instructor-centered' [24]. xMOOCs and $\mathrm{CMOOC}$ could be most suitable for a specific learning domain. For instance, Engineering which has more technical open online courses could be more suitable for $\mathrm{XMOOCs}$ while $\mathrm{CMOOCs}$ could be more suitable for social sciences [25]. Table 1 illustrates MOOCs types and relevant learning theories.

There are learning theories which support using MOOCs as an extension to the e-learning process. These theories can be divided into two learning theories, cognitivebehaviorist learning theory and connectivist learning theory. Cognitive-behaviorist theory supports xMOOCs and concentrates on learners as individuals. In addition to that, it focused on the contents.

In contrast, the connectivist theory which supports cMOOCs has concentrated on people, information and resources as networks through linking knowledge with people, resources and information by offering a sharing personal knowledge. Table 1 illustrates the learning theories of MOOCs.

Furthermore, the online collaborative learning theory proposed by Linda Harasim [26] can support the collaboration between MOOCs providers to enhance the quality of material contents and offering sharing knowledge.

Table 1: Types of MOOCs and Learning Theories

\begin{tabular}{|c|c|c|c|c|}
\hline \multirow{2}{*}{ Author } & \multicolumn{4}{|c|}{ MOOCs types and relevant learning theories } \\
\hline & MOOC models & Learning theory & Focused domain & Theory description \\
\hline $\begin{array}{l}\text { Anderson and } \\
\text { Dron, 2011; } \\
\text { Meltem Baturay, } \\
\text { 2014; Siemens, } \\
2012\end{array}$ & $\mathrm{xMOOC}$ & $\begin{array}{l}\text { Cognitive- } \\
\text { behaviourist }\end{array}$ & Individuals & $\begin{array}{l}\text { The learning process is } \\
\text { described as 'instructor- } \\
\text { centered'. xMOOC is } \\
\text { described as 'content-based' } \\
\text { MOOC. }\end{array}$ \\
\hline $\begin{array}{l}\text { Siemens, 2013; } \\
\text { Abram Anders, } \\
2015\end{array}$ & cMOOC & $\begin{array}{c}\text { Connectivism } \\
\text { theory }\end{array}$ & $\begin{array}{l}\text { Networks of } \\
\text { people, } \\
\text { information, } \\
\text { and resources }\end{array}$ & $\begin{array}{l}\text { The learning process is viewed } \\
\text { as the process of creating and } \\
\text { relating divided nets of } \\
\text { learners and lecturers, } \\
\text { information, and resources } \\
\text { that offer an integrated } \\
\text { sharing knowledge among } \\
\text { them }\end{array}$ \\
\hline
\end{tabular}


In order to illustrate the MOOC concept, figure 1 demonstrates the meaning of $M O O C$ and difference between $X M O O C$ and $C M O O C$ and its role to enhancing the e-learning process.

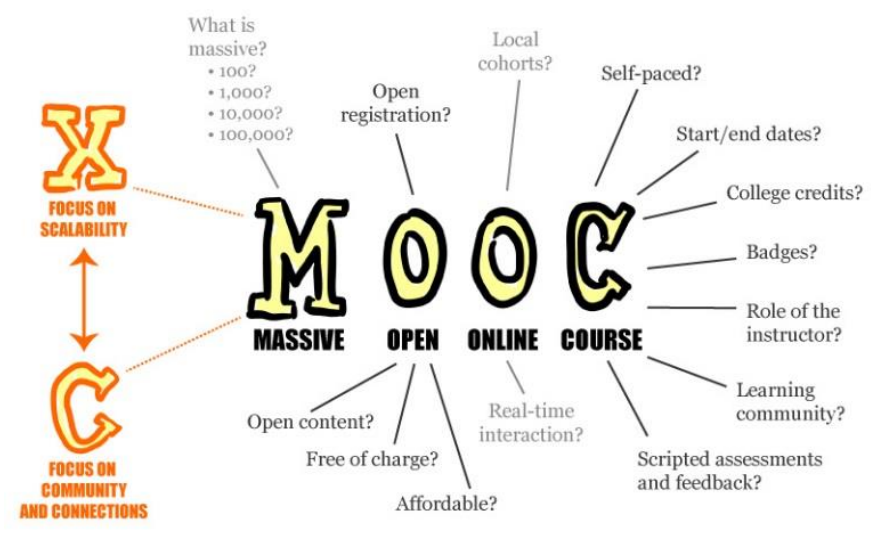

Figure1: MOOCs concept [27]

In defining MOOCs words for words, the term "massive" indicates that a large number of students may enroll in MOOCs. "Open" means that it implements an open platform for registration, consists of open contents and the courses are mainly free of charge. The term "online" in a generic sense refers to the accessibility of the offered courses via the internet, and finally the term "courses" indicates that the offered courses are integrated and not fragmented. These courses allow learners to benefit from studying in their selfpaced".

Furthermore, the previous studies on e-learning success model did not take into account the individual impact [28]. Moreover, even some studies which considered individual impact have not focused on the organizational impact such as information, resources and networks of its people and individual as learners together [29] [30] [31]. Future research will focus on both individual impact and organizational impact towards e-learning success and MOOCs.

However, existing collaboration between MOOCs seems to be scarce. It is expected that such collaboration may expand the variety of offered courses and ensure the best quality of the e-learning experiences. In a collaborative setting, it is possible for a renowned instructor from MOOC $A$ in University $A$ to deliver his lectures to other MOOCs ( $B, C$ and D) from other participating universities. Students in the participating universities can benefit from the offered advanced courses, contents and its innovative various courses and various learning methods where some lecturers have different teaching methods from others. Figure 2 illustrates the proposed collaboration between MOOCs.

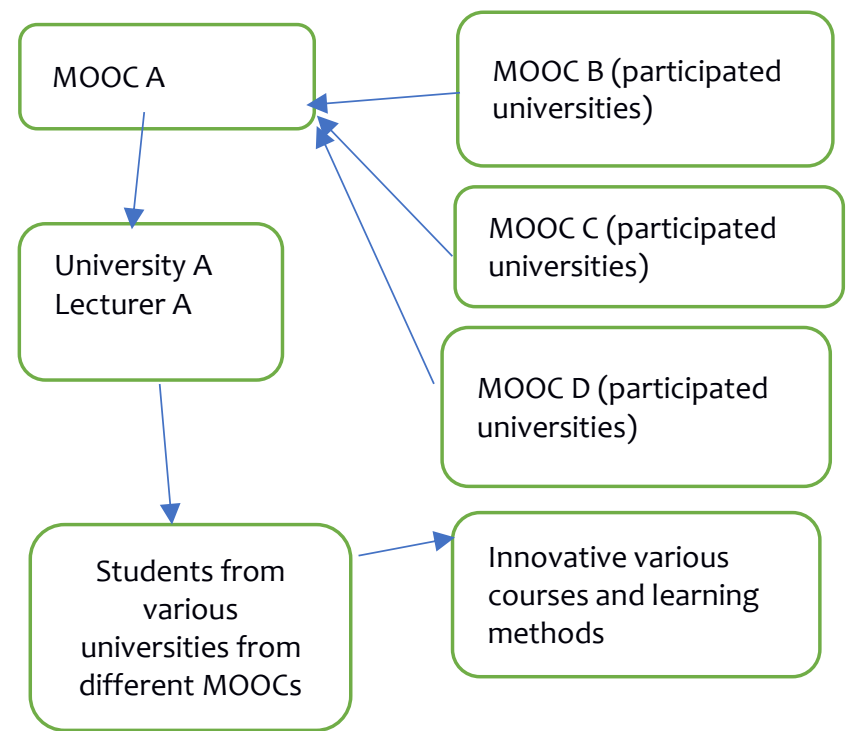

Figure 2: The collaboration among universities through MOOCs

\section{CONCLUSION}

In this paper, we have reviewed the widespread use of MOOCs around the world, models and types, its practical implementation in e-learning LMS and its theoretical role in supporting e-learning theories. This paper partly concentrated on the role of MOOCs in promoting the elearning process through the direct relationship between MOOCs models and two learning theories and its role in promoting both individual e-learning and the socially networked e-learning. This direct relationship can be explained through the main depending on xMOOCs on cognitive-behaviorist learning theory and depending on cMOOCs on the connectivism learning theory. In addition to that, the online collaborative learning theory could improve the quality of the e-learning through offering the collaboration between MOOCs providers which could benefit learners in sharing knowledge and enhance the studying material content and offering joint lecturer among MOOCs. Also, this paper focused on MOOCs implementation with LMS and cloud-based tools and the ability to use it as SOA. MOOCs have attracted many thousands of learners from all over the world. Based on the observation and examination of the existing offered opened online courses in MOOCs and its learning outcomes, this paper concludes that MOOC is an innovation extension of e-learning and it can be considered as a very important milestone in the development of higher education and one of the main factors contributing to prosper and success of the e-learning process. Hence, MOOCs brings a revolt to the e-learning and the education process. 


\section{REFERENCES}

[1] M. Simonson, S. E. Smaldino, M. Albright, and S. Zvacek, "Teaching and Learning at a Distance: Foundations of Distance Education”. Allyn \& Bacon: Boston, 2011.

[2] L. Pappano, "The Year of the MOOC", 2012.

[3] The New York Times. "The Big Three, at a Glance". The New York Times, 2012.

[4] edX. "edX partnering”, 2017.

[5] T. Lewin, "Universities abroad joint partnerships on the web". New York times. February 20, 2013.

[6] M. S. Ramirez, "Guidelines and success factors identified in the first MOOC in Latin America. EDULEARN14, 6th International Conference on Education and New Learning Technologies, pp. 3042-3051, July 2014. Retrieved from http://catedra.ruv.itesm.mx/bitstream/987654321/840/2/Guidelines and success factors identified in the first MOOC in Latin America.pdf

[7] A. Marszal, "UK universities to lunch free degree-style online courses". London: telegraph, 2012, retrieved on 12 January 2017, from http://www.telegraph.co.uk/education/educationnews/9743703/UKuniversities-to-launch-free-degree-style-online-courses.html

[8] FutureLearn partners and courses. Retrieved on January 21, 2017, from https://www.futurelearn.com/.

[9] N. Lumas, “Berlin-based iversity relaunches as MOOCs platform, sets its sights on becoming the coursera of Europe, posted on March 11, 2013. Retrieved on January 21, 2017, from https://techcrunch.com/2013/03/11/iversity-moocs-pivot/

[10] Iversity MOOC. About Iversity MOOC. Retrieved on January 21, 2017, from https://iversity.org/en/pages/about.

[11] B. Kim, W. Ying, K. Pushpanadham, T. Yamada, T. Lee, M.Fadzil, M. and I. Gil-Jaurena, MOOCs and Educational Challenges around Asia and Europe (Vol. 1), 2015.

[12] M. Jemni, and M. K. Khribi, “Open Education: from OERs to MOOCs", Springer Berlin Heidelberg, 2016. Retrieved from https://books.google.com.my/books?id=MWTUDAAAQBAJ
[13] Japan MOOC. About JMOOC. Retrieved on January 21, 2017, from https://www.jmooc.jp/en/.

[14] OpenLearning MOOC. Malaysia MOOC. Retrieved on January 21, 2017, from https://www.openlearning.com/malaysiamoocs.

[15] edX MOOC. Edraak MOOC in Jordan. November 13, 2013. Retrieved on January 22, 2017, from http://blog.edx.org/moocs-arab-world.

[16] edraak MOOC. "Edraak- towards a better Arab world”. July 2014.

[17] edraak MOOC. Retrieved on January 23, 2017, from https://www.edraak.org/en/

[18] Rwaq MOOC. Rwaq MOOC courses. Retrieved on January 22, 2017, from https://www.rwaq.org/.

[19] N. Curley, "Saudi Arabia's Rwaq builds an online courseware platform for Middle East". In Wamda Blog, December 2013. Available: http://www.wamda.com/2013/12/saudi-arabia-rwaq-onlinecourseware-mooc-middle-east [Accessed 1-22-2017].

[20] A. Muscara, B. Bassem, Co-Founder of SkillAcademy.com. In Scoop Empire, March 3, 2014. Available: http://scoopempire.com/qa-bassemfayek-co-founder-skillacademy-com/ [Accessed 1-22-2017].

[21] RESCIF MOOC, "Collaboration in making MOOC courses in Africa”, Retrieved on January 22, 2017, from http://www.rescif.net/fr/content/appel-projets-de-moocs-collaboratifs.

[22] N. A. Adzharuddin, and L. H. Ling, "Learning management system (LMS) among university students: Does It Work?" International Journal of E- Education, E-Business, E-Management and E-Learning, vol. 3, no. 3, pp. 248-252, 2013.

[23] M. Blagojevi, and D. Milo, "Massive Open Online Courses: edX vs Moodle", 5th International Conference on Information Society and Technology, pp. 346-351, 2015.

[24] C. Meinel, M. Totschnig, and C. Willems, “openHPI: Evolution of a MOOC Platform from LMS to SOA", Proceedings of the 5 th International Conference on Computer Supported Education, 593-598, 2013.

[25] L. Uden, Y. Tao, H. Yang, and I. Ting, Lorna Uden Yu-Hui Tao HsinChang Yang I-Hsien Ting, 2013.

[26] L. Haraasim, “learning theory and online technologies", 2012.

[27] B.Atanda, "Factors contributing to e-learning success in Nigeria institutions of Higher Learning”, 2016.

[28] R. Kope and H. Fournier, "social and affective presence to achieve quality learning in MOOCs", 2013. 